\title{
Relevant Aspects in the Commercial and Financial Relations between Mexico and the USA and Its Continuity in the New Trump Administration
}

\author{
José Francisco Reyes Durán \\ Escuela Nacional de Estudios Superiores, Universidad Nacional Autónoma de México, México
}

Copyright $\mathrm{C} 2018$ by authors, all rights reserved. Authors agree that this article remains permanently open access under the terms of the Creative Commons Attribution License 4.0 International License

\begin{abstract}
The banking system that operates in the country will not have major changes, with the arrival of Trump to the presidency of the USA. Surely, it will continue to operate as it has until now, concentrating the financing to large companies and the government; providing credit on payroll and mortgage are the least risky and most profitable; managing derivative products (even in dollars given the strong expected volatility), and charging all kinds of commissions. It is even envisaged that its dominance could be expanded by deregulation of the rules adopted since the financial crises of 2007-2009. This paper analyzes three aspects: some minskian theoretical views on debt, economic openness and financial instability; some economic - financial links between Mexico and the United States, and the recent situation of banking at the international level and in Mexico. The method used is simple, based on a heterodox theoretical framework, a statistical analysis is carried out that allows identifying economic and financial variables that allow valuing the strong relations between both countries. With this diagnosis its possible glimpse some trends. It is concluded that it is difficult for Mexico to make significant changes in its economic and financial position, unless there is a change in the negotiation of NAFTA or in the economic policy of both countries.
\end{abstract}

Keywords Banking, Debt, Mexico-US Relations, Liability, Monetary Policy, Ponzi Economy

\section{Objective and Methodology}

This article aims to show that the change in the administration of the presidency of the United States, with the arrival of President Donald Trump, does not imply significant changes that could benefit Mexico, despite the possible renegotiation of NAFTA and his protectionist stance

From a methodological point of view, a bibliographical review of post-Keynesian and heterodox theory (Minsky, Keynes, Mantey, Toporovsky) was carried out in relation to three themes: debt, economic openness, and financial instability, levels that they can be interpreted based on the hypothesis of Minsky's financial instability to show that the dependency traits of Mexico with respect to the US are perpetuated. From here an analysis of economic financial variables is carried out, confirming the strong dependence of Mexico with respect to the neighbor to the north. The third part proves that the integration of Trump's cabinet does not imply significant changes in the treatment of its economic policy, since a good part has representatives of the financial, military and republican groups that is the party from which it comes. All this allows to consolidate the idea that the financial oligarchy will continue with the hegemonic role in the environment of the relations between both countries.

\section{Theoretical Appraisals: Debt, Economic Opening and Financial Instability}

There is much literature related to the studies on financial instability, originally created by Keynes and later by Minsky, Toporovsky and others. In all cases, they focus on the causal phenomena of investment theory, business cycles and phenomena that accompany corporate leverage and debt.

Specifically, what is relevant in Minsk's theory is that its postulates have applications at three levels: in firms and families, in sectors or branches of economic activity, and at the level of a country and its links to international finance, specifically through flows of investment (productive or financial) throughout the world.

The three levels of analysis can be interpreted on the 
basis of the hypothesis of financial fragility. This fragility can be accelerated by a number of factors: capital or investment flows, interest rates, the level of credit or indebtedness, the exchange rate, international reserves, and country risk as the most significant.

In this sense, the key to financial crises seems to be found in the way economic agents (individuals, companies and governments) organize their administration and financing structure, mainly credit, which generates the economic cycle that can put the economic performance and turn companies, sectors or economies as a whole into areas with strong liquidity and indebtedness problems, and even lead to depression.

Mexico, in particular, is immersed in a totally open economy, situation that places it in a highly vulnerable scenario that can even condition its growth and economic development. The possibility that international capital flows through foreign investment (direct or portfolio, or both), and external credit financing through transnational banking, or other sources, may represent serious threats to country sovereignty and reduce the action margins of the monetary and fiscal policy instruments.

Minsky [1] in his paper: The Financial Instability Hypothesis, analyzes the state of the borrowing process. He postulates that the evolution of financial practices and the structure of commitments of this nature are the most important causes of changes in the economy, since they mark the destination of business and influence decisively in the making of investment decisions.

As it is widely known, Minsky [2] contemplates three types of scenarios: covered company (which can effectively attend to its financial commitments), speculative (which must renegotiate its financial commitments) and Ponzi (a company that must contract new debt to cover the debt previous).

Previously, Keynes in his Tratise on Money [3] pointed out that credit is the link between the present and the future; while Polanyi [4] in his book: The Great Transformation, specified that credit is the chain between the productive systems and financial space and that when it breaks, it can -even- lead to war. In this line, even a former Mexican Secretary of Finance has pointed out that credit is the central nervous system that flows through all economic activity [5]. The credit is also found, endogenously determined by the anticipated requirements of the means of payment. From this perspective, the credit phenomenon is enormously relevant for understanding economic dynamics.

Some factors that determine the levels of indebtedness will be identified below: in their level, behavior and structure and in the conditions in which it can lead to crises.

The interpretations to which reference will be made are found in Post Keynesian works, essentially by Blancas [6] and by Melo [1], who are part of a more developed model of open economy and government. Also, the work of Mantey [7] was considered, specifically, the monetary approach of adjustment of the balance of payments and its effect on the contraction of domestic credit.

For a closed economy, it can be say that a covered economy is when its income or income is greater than the sum of debt service (interest payments and principal) plus investment, which implies that external funds (or debt) can be fully covered. For a speculative economy, yields or income are higher than debt service, but less than the sum of debt service plus investment, it implies that external funds are less than investment and debt is not covered totally, persists.

Finally, in a Ponzi economy, its income is less than the debt service and, therefore, the external funds are greater than the investment. This implies a permanent debt spiral.

So, what factors determine sources of external or credit financing? The answer to this question lies in a number of factors, including the asset growth rate (debt increase), the rate of profit (debt reduction), the amount of assets themselves debt the interest rate (increases the debt) and the incidence that the interest rate has on the total stock of debt (debt increases). Note that of all the factors mentioned, the only one that does not increase indebtedness are the benefits, which decrease it.

In an open, and more realistic, economy these factors are compounded by more complex ones. A covered economy would be where yields must be greater than or equal to the sum of domestic debt plus the effect of the exchange rate on external debt, plus investment, where in the end total debt is less than, or equal to, zero.

A speculative economy will be one where the yields are greater than or equal to the domestic debt plus the effect that the exchange rate has on the external debt, which implies that the total debt will be greater than zero. Finally, a Ponzi economy is characterized by the yields which are smaller than the sum of domestic debt plus the effect of the exchange rate on external debt, which implies that the total debt is greater than the investment requirements.

In summary, the level of debt, as a dependent variable, is determined by:

- Asset growth rate,

- Benefit rate,

- Total amount or stock of assets,

- Domestic interest rate on domestic debt,

- External interest rate of the foreign debt contracted,

- The domestic and foreign interest rate differential (country risk).

In an open economy, such as Mexico, which is also governed by monetarist principles of the balance of payments, there is freedom (openness) in the capital account where the authorities seek to attract foreign investment, both portfolio and direct [ $8 \& 22]$. The total freedom to enter and exit capital flows implies that in order to compensate them they will have to be sterilized (avoiding their inflationary effect) by contracting domestic credit in the same proportion:

In order to maintain price stability by sterilizing reserves and / or ensuring an overvalued exchange rate, which 
guarantees the exchange premium to international capital, the Central Bank accumulates international reserves during the investment boom process, International reserves reflects the growing accumulation of liabilities with the outside world and create a false illusion of the ability to pay the economy. This fact stands out when the Central Bank sterilizes reserves by contracting domestic credit, that is, replacing domestic credit with external credit [emphasis added], since sterilization in itself induces the increase of capital flows by the effects Which has on the interest rate; Economic units and the economy as a whole increase their level of financial fragility, although reserves increase. [And citing Kregel, 2009: 16 notes that: inadequate responses to the latest crisis led developing countries to sustain higher levels of reserves, contributing to large global imbalances ...] [1].

Government measures of open trade and capital are based on the monetary approach of the balance of payments

If the country requires a greater amount of foreign exchange, for example to cover amortizations of its external debt, then, according to this approach, greater control over domestic credit should be exercised [the emphasis is proper], maintaining the money supply by Below the estimated demand. On the other hand, if the level of international reserves allowed to finance a deficit with the outside world, monetary authorities could tolerate a greater expansion of domestic credit and income, with money supply growing above expected demand [7].

In conclusion, in Mexico's bank credit financing is constrained, especially for small and medium enterprises, while several of the large ones have been placed under financial structures classified as speculative or even Ponzi.

Monetary policy has played a central role in this scheme of economic financing. The banking sector has seen its participation in the economy benefited by the policies that reproduce this functioning: high interest rates, contraction of domestic credit, opening up of foreign capital, banking deregulation, sterilization of capital inflows through international reserves mechanisms and decrease bank credit; contraction of the money supply (accompanied by auctions of forwards of exchange rates made by BANXICO, all this has concrete benefits for the commercial bank). The dissociation between the passivity of the Central Bank to reactivate the economy and fiscal policies of zero deficit, i.e., contraction of public expenditure come to round the stage. The policy of overvaluing the exchange rate to benefit product imports, while exports use the contraction of wages as a cost mechanism to support the competitiveness of exports has direct implications for the slowdown of the domestic market. In the last days of March 2017, the Central Bank raised benchmark interest rates from $3 \%$ to $6.50 \%$ per annum, 3.5 percentage points.

\section{Economic-Financial Links between Mexico and the United States of America (USA)}

It is much easier for the third world war to erupt next year when there are radical changes in NAFTA, it would be extremely disturbing for Mexico and the United States to thwart the integration of production chains in the automotive [...] industry, there are assembly or engineering plants In Mexico taking components from Canada, the United States and vice versa [...] in the only areas where there could be changes to the treaty would be aspects related to labor relations and environmental care [9].

This section analyzes the main commercial and financial aspects between Mexico and the United States. It is argued that it will hardly bring about significant changes in economic - financial relations between the two countries. The US is by far the largest recipient of Mexico's agricultural and manufacturing exports and is also the main source of portfolio investment and foreign direct investment flows to Mexico, which explains the close correlation of the economic cycles of both Economies. The information presented in this section was taken essentially from the IMF Report for Mexico No. 15/314, dated November 2015.

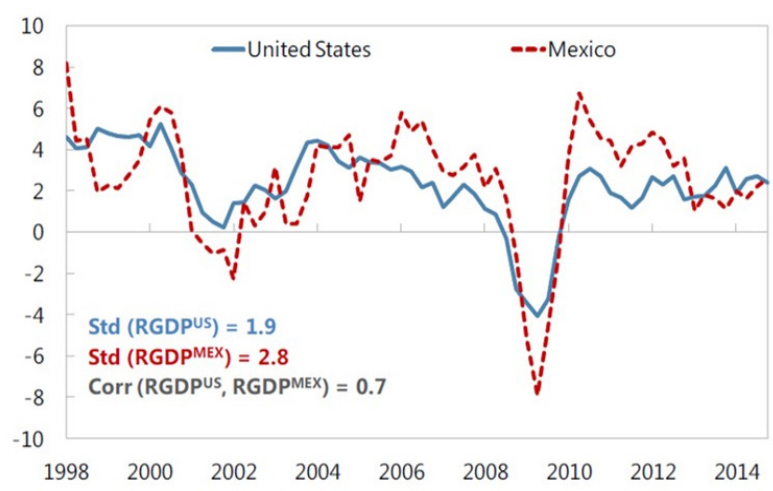

Source: National Authorities; IMF Staff calculations.

Figure 1. U.S. and Mexico Real GDP Growth (In Percent)

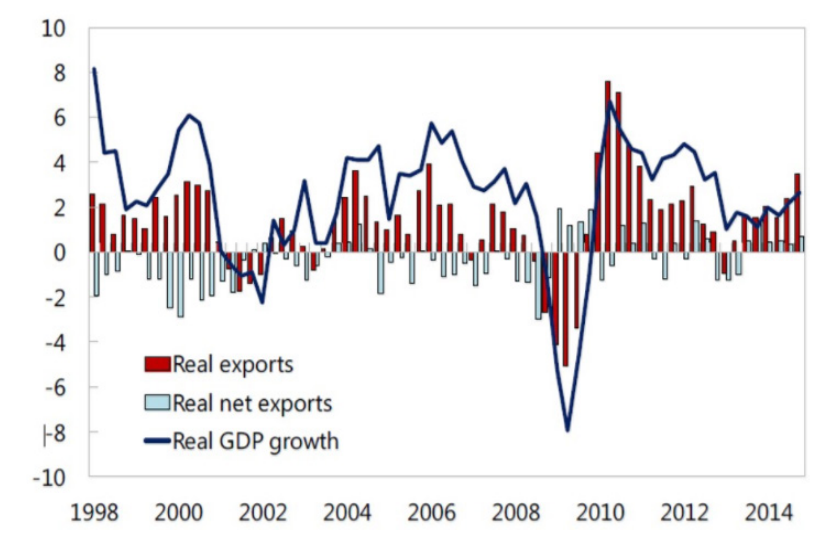

Source: National Authorities; Haver Analytics; and IMF Staff Calculations.

Figure 2. Mexico: Contribution to GDP Real Growth (In Percent) 
Mexico's strong ties with the US have benefited the northern neighbor over the years; however, this relationship is not free from shocks, adjustments and uncertainty: they expose the country to fluctuations in economic activity and changes in its monetary conditions. On the other hand, the opening of the capital account and the large foreign holdings of Mexican assets expose Mexico to financial effects, including the possibility of abrupt changes in capital flows.

Briefly, some aspects that have potential effects on the Mexican crisis are indicated:

- Export growth is a key element of economic activity, with indirect effects on domestic demand, but has not resulted in a better distribution of income or employment. An eventual fall of these - as it has happened in the two recent months of 2017 - causes problems in the companies dedicated to the external activity.

- $\quad$ Although international agencies are keen to point out that the US banking system is resistant to severe shocks, they are strongly tied to insurance companies, hedge funds and other managed funds - either through the financial groups that comprise them, or by the volume and depth of the financial transactions that interrelate them - and thus contribute to global financial risks in a proportion greater than the one suggested by their size, and therefore deserve much attention.

- The close economic and financial relationship between these two countries can deepen Mexico's problems if there is an increase in US bond yields that is not accompanied by a further growth of the US economy with negative effects on domestic production.

- $\quad$ By mid-2015, international investors held about half of Mexico's total public debt (including 36\% of government bonds in local currency), as well as a large portion of corporate bond debt. In this way, gross portfolio investment liabilities in Mexico represent $37.5 \%$ of GDP, of which $25 \%$ are debt securities.

\section{Business Links}

Since NAFTA was signed in 1994, Mexican exports have increased fivefold: the automobile industry and the telecommunications sector accounted for part of the expansion.

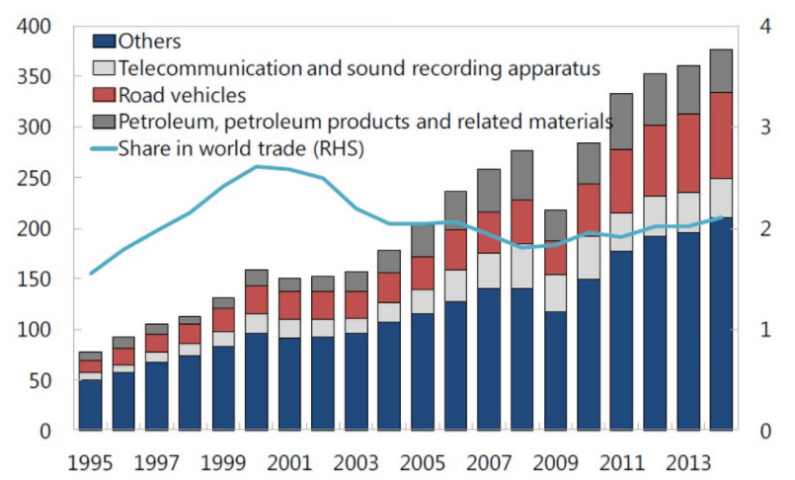

Source: UNCOMTRADE; And IMF Staff Calculations.

Figure 3. Mexico: Total Exports of Goods (USD, Billion)

Mexico's share of the world of exports also increased somewhat after NAFTA, and has stabilized around 2\% recently. The United States remains as the main partner, accounting for $80.5 \%$ of total exports. Canada represents only $2.7 \%$. The three most important partners after the USA and Canada are: Spain, China and Brazil which mean about $1.5 \%$ each.

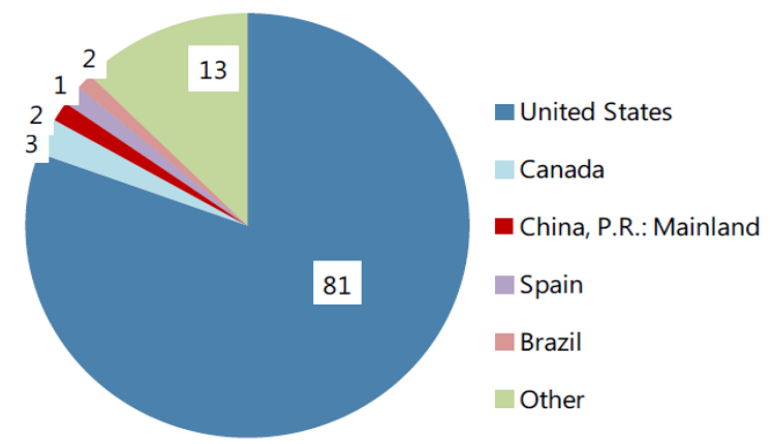

Source: Direction of Trade Statistics; IMF Staff Calculations.

Figure 4. Mexico: Total Exports by destination. 2014 (In percent of total)

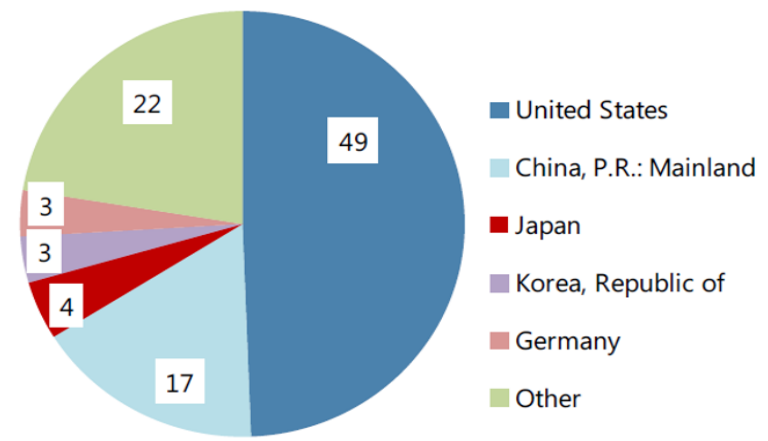

Source: Direction of Trade Statistics; IMF Staff Calculations.

Figure 5. Mexico: Total Imports by Origin. 2014 (In percent of total) 
In the case of Mexican imports, $49 \%$ come from the USA, $17 \%$ from China and $4 \%$ from Japan: $70 \%$ from the three countries.

Highlights Mexico's recovery from the US market share in recent years due, in part, to changes in labor costs relative to Mexico: Mexico's average wage cost vis-à-vis China is at half, is less than $\$ 100$ a month, compared with double Chinese wages (just over \$200).

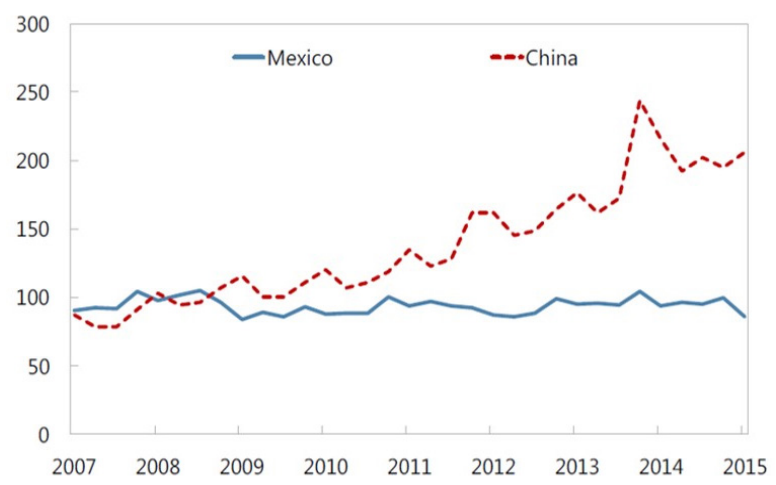

Source: National Authorities; Haver Analytics; and IMF Staff Calculations.

Figure 6. Mexico - China Unit Labor Cost (Index, 2008=100)

Summing the exports and imports to determine Mexico's total share of the US market, it can be noted that it has remained stable at around $10 \%$ because in the early 2000 s, China started acquiring market share in the US after joining the World Trade Organization [10]; however, as discussed previously, Mexico has regained its participation in recent years, in part because of changes in labor costs relative to Mexico.

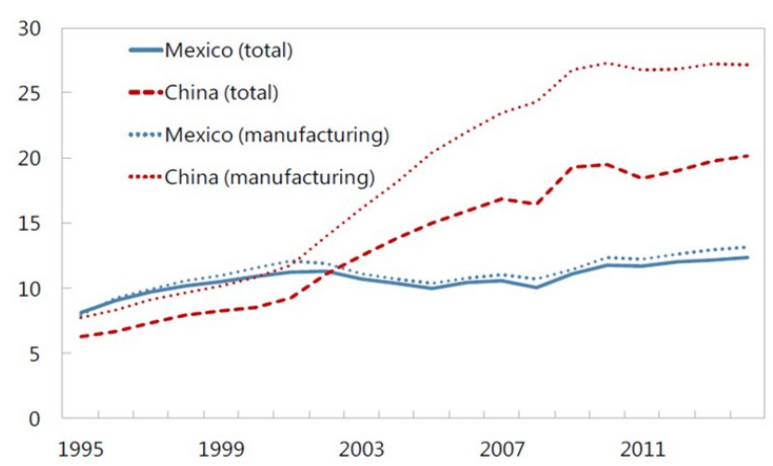

Source: UNCOMTRADE; And IMF Staff Calculations

Figure 7. U.S. Trading Partners (Share of U.S. Imports)

Industrial production has been highly correlated with the United States, reflecting Mexico's integration into the value chains of North American production. The detailed breakdown of sectors suggests strong integration in manufacturing, especially in chemical and machinery industries. Mexico's Central Bank [10] shows a high correlation between Mexican exports and US industrial production. In addition, the analysis shows that Mexican and American industrial production coincide and follow a common cycle.
Table 1. Mexico and U.S. Industrial Production (Correlation)

\begin{tabular}{|cc|}
\hline Sector & Correlation \\
\hline Total & $\mathbf{0 . 9 4}$ \\
\hline Mining & $\mathbf{- 0 . 2 5}$ \\
\hline Utilities & $\mathbf{0 . 8 9}$ \\
\hline Electric power & 0.90 \\
\hline Manufacturing & $\mathbf{0 . 9 3}$ \\
\hline Paper & -0.85 \\
\hline Printing & -0.38 \\
\hline Petroleum and coal & 0.66 \\
\hline Chemical & 0.88 \\
\hline Plastics and rubber & 0.30 \\
\hline Nonmetallic minerals & 0.01 \\
\hline Primary metal & 0.47 \\
\hline Fabricated metals & 0.64 \\
\hline Machinery & 0.73 \\
\hline Computer and electronics & 0.26 \\
\hline Electrical equipment and appliances & 0.00 \\
\hline Furniture & 0.34 \\
\hline
\end{tabular}

Source: National Authorities; IMF Staff calculations.

\section{Financial Links}

The portfolio liabilities of various financial instruments are in the hands of foreigners and have increased steadily over the years:

- In 2015, the largest increase in foreign ownership occurred in bonds denominated in national pesos, of which foreign agents hold about $11 \%$ of GDP, 144 billion dollars (well over the total amount of International reserves of those years), which establishes a technical imbalance, with scenarios of potential crisis.

- There is also an increase in private sector bonds issued abroad (at another exchange rate), which accounted for $2.5 \%$ of GDP in 2002 and increased to $5.8 \%$ of GDP ( $\$ 75$ billion) in 2014. In a certain way, this reflects a substitution of external borrowing for bond debt as total private sector debt increased more slowly from $8.7 \%$ of GDP in 2002 to $10.5 \%$ in 2014 .

- Mexican holdings by non-residents also doubled since 2002, reaching almost 12\% of GDP in 2014 . About half of the foreign investment and direct investment liabilities are held by US investors.

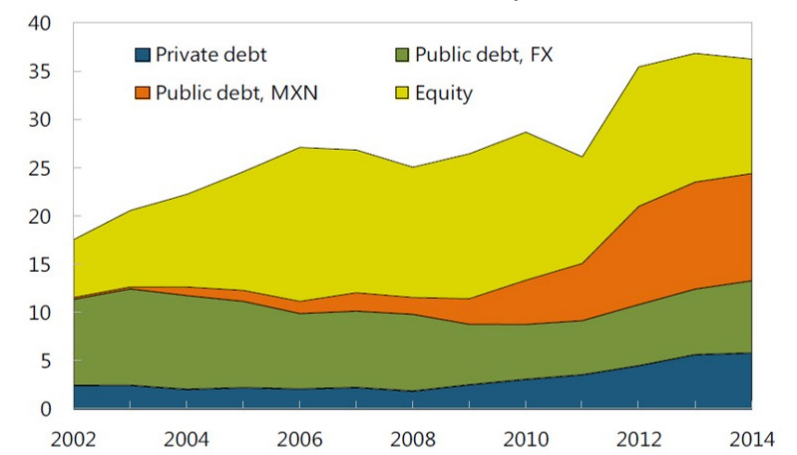

Source: National Authorities; IMF Staff calculations.

Figure 8. Nonresidents' Holdings of Portfolio Liabilities (In percent of GDP) 


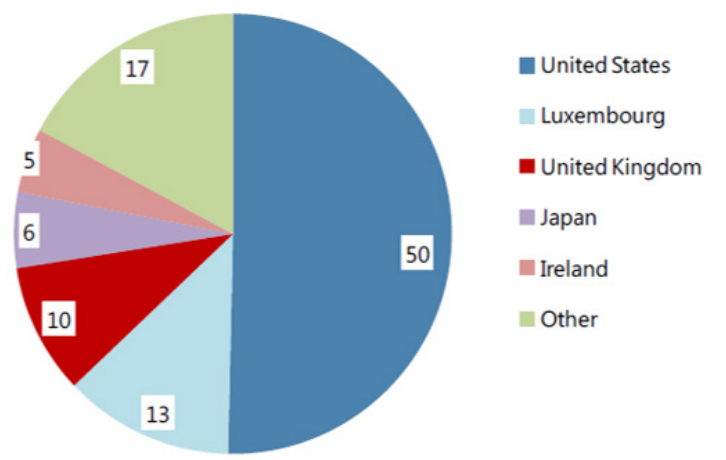

Source: Coordinated Portfolio Investment Survey (2014); and Coordinated Direct Investment survey (2013).

Figure 9. Foreign Portfolio Liabilities by Source Country. 2014 (In percent of total)

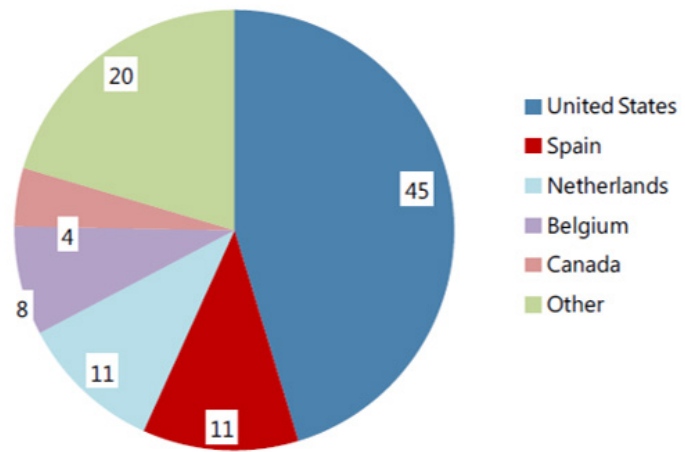

Source: Coordinated Portfolio Investment Survey (2014); and Coordinated Direct Investment survey (2013).

Figure 10. Stock of Inward FDI by Source Country. 2013 (In percent of total)

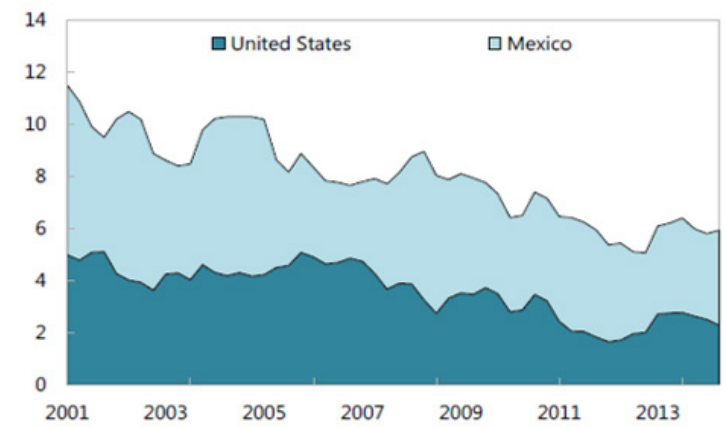

Sources: Bloomberg L.P.; Haver Analytics; and IMF Staff Calculations.

Figure 11. Ten Year Government Bond Yields. (In percent)

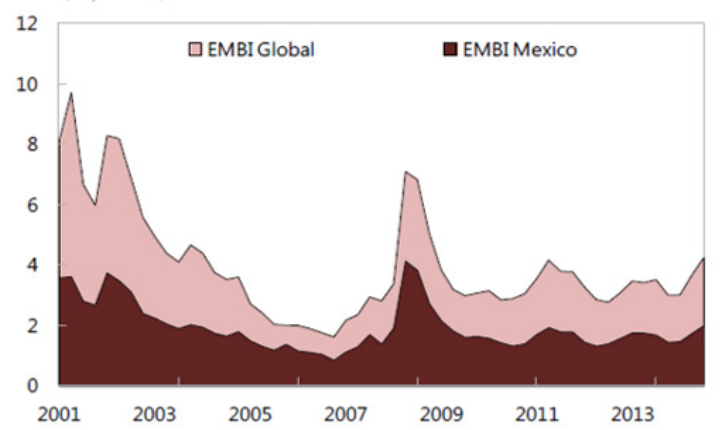

Sources: Bloomberg L.P.; Haver Analytics; and IMF Staff Calculations.

Figure 12. EMBI Spreads (In percent)
In 2013, by country of origin, FDI was concentrated in the US with $45 \%$, followed by Spain and the Netherlands with $11 \%$ each one, and Belgium and Canada both with $4 \%$ each. These five countries account for $75 \%$ of FDI in Mexico.

Long-term interest rates and the spread dynamics in Mexico are significantly influenced by external developments. Long-term yields on 10-year government bonds in Mexico have fallen from $11.5 \%$ in 2001 , to around $-6 \%$ in mid-2013; during this period US bonds also fell from 5.5\% to 3.5\%; however, since mid-2013, Mexican yields have increased, while US yields have continued to fall, on the one hand, by the global attitudes assumed towards risk, and on the other hand by EMBI's global differentials (Emerging Markets Bonds Index), or Emerging Markets Bond Indicators, which also affected Mexico's risk spreads. It is observed that Mexico's interest rates react strongly to changes in US rates.

US long-term interest rates reflect the expected trajectory of US monetary policy, its expected economic performance and general attitudes to risk, where each of these components may affect Mexico differently. Therefore, 10-year US bond yields compared to domestic bonds play their role in real, monetary, and risk shocks [11], shocks caused by risk appetite.

External factors, commercial and financial, played a significant role in slowing Mexico's growth during global financial crises: the country's economic situation during the years 2013-14, clearly reflects the contraction of construction activity in 2013 and lower production of oil, two elements that influenced the fall in economic activity.

\section{The Cabinet of the Administration of Donald Trump}

The cabinet of the current administration of Washington consists essentially of 29 personalities: 11 of them are strongly linked with the business sector from the president himself with his real estate business, to his advisory council where there are companies of high technology, refreshments, oil and restaurants; without discarding two personalities strongly related to the financial system: Steven Mnuchin, banker and Gary Cohn, Chairman of the Goldman Sachs Banker Group, who would hold the positions of Secretary of the Treasury and Head of the National Economic Council, respectively.

Another important group of 13 people, the most numerous, is composed of Republicans, which shows strong alliances with his party, despite the possible confrontation with some of its members. The third group comprises four key actors in US military security and interests, and only one person does not belong to any of the above groups: the Chief of the Environmental Protection Agency, which shows evidence of the little importance that this administration will give to the subject. 

the USA and Its Continuity in the New Trump Administration

Table 2. Donald Trump's Cabinet

\begin{tabular}{|c|c|c|}
\hline Name & Position & Antecedent \\
\hline \multicolumn{3}{|r|}{ Bussines Links } \\
\hline Donald Trump & President & Great Real Estate Entrepreneur, Casinos, Hotels, Luxury Homes \\
\hline Elon Musk & Member of the Advisory Board & CEO of Space $\mathrm{X}$ and Tesia \\
\hline Travis Kalanick & Member of the Advisory Board & Co-founder of Uber Tecnologics \\
\hline Indra Nooyi & Member of the Advisory Board & Head of PepsiCo. \\
\hline Rex Tillerson & Secretary of State & $\begin{array}{l}\text { Head of Exxon-Mobil Corp. } \\
\end{array}$ \\
\hline Andrew Puzder & Secretary of Labor & General Manager of Restaurants Holding, Matrix of Carl's Jr Hardee's \\
\hline Wilbor Ross & Secretary of Commerce & $\begin{array}{l}\text { Multimillionaire. King of Bankruptcy (buy companies in bankruptcy). Fortune close } \\
\text { to } 3,000 \text { mdd. }\end{array}$ \\
\hline Donald McGhan & Presidential Assistent & He works for a law firm in Washington and was Trump's advisor in his campaign. \\
\hline $\begin{array}{c}\text { KathleenTroia } \\
\text { McFarland }\end{array}$ & Deputy Minister of National Security & Fox News Commentator. I worked in the Nixon, Ford and Reagan administrations. \\
\hline \multicolumn{3}{|r|}{ Links with banking } \\
\hline Steve Mnuchin & Secretary of the Treasury & $\begin{array}{c}\text { Banker } \\
\text { Head of the Trump Campaign }\end{array}$ \\
\hline Gary Cohn & $\begin{array}{l}\text { Head of the National Economic } \\
\text { Council }\end{array}$ & $\begin{array}{c}\text { President of Banking Group Goldman Sachs. Coordinate the President's Economic } \\
\text { Agenda. }\end{array}$ \\
\hline \multicolumn{3}{|c|}{ Links with the Republican Party } \\
\hline Mike Pence & VicePresident & Christian, ultraconservative and republican. \\
\hline Kushner & Adviser & Trump's son-in-law \\
\hline Reince Priebus & Chief of Staff & $\begin{array}{c}\text { President of the Republican National Committee } \\
\end{array}$ \\
\hline Ricky Perry & Secretary of Energy & $\begin{array}{l}\begin{array}{l}\text { Former Governor of Texas. Republican who proposed to remove the Secretariat of } \\
\text { Energy. }\end{array} \\
\end{array}$ \\
\hline Cathy McMorris & Secretary of Interior & \begin{tabular}{|l|} 
Republican Congressman. \\
\end{tabular} \\
\hline Terry Branstad & Ambassador of China & $\begin{array}{c}\text { Former governor of Iowa } \\
\text { Trump Exrival in the Primary Elections }\end{array}$ \\
\hline $\begin{array}{l}\text { Ben Carson } \\
\text { (black) }\end{array}$ & $\begin{array}{l}\text { Secretary of Housing and Urban } \\
\text { Development }\end{array}$ & Republican. Trump Contestant in the Primary Elections. \\
\hline Elaine Chao & Secretary of Transportation & Former Secretary of Labor in Administration G. W. Bush. \\
\hline Tom Price & $\begin{array}{l}\text { Secretary of Health and Human } \\
\text { Services }\end{array}$ & $\begin{array}{l}\text { Republican Congressman. } \\
\text { It is said that he will be in charge of dismantling Obamacare. }\end{array}$ \\
\hline NikkyHaley & US Ambassador to the UN & Governor of North Carolina \\
\hline Steve Bannon & $\begin{array}{l}\text { Trump Advisor and Chief Strategist } \\
\text { at the UN }\end{array}$ & $\begin{array}{l}\text { Former Campaign Manager for Trump. Former Site Director "Beitbart News". } \\
\text { Promotes White nationalism }\end{array}$ \\
\hline Jeff Sessions & Attorney General & $\begin{array}{l}\text { Republican Senator from Alabama. Opposer to the Immigration Reform. He has } \\
\text { made racist comments. He opposed projects to regularize migrants. }\end{array}$ \\
\hline Betsy de Vos & Secretary of Education & Republican of the State of Michigan. Leads the American Federation for Children \\
\hline \multicolumn{3}{|r|}{ Military and Security Links } \\
\hline John Kelly & $\begin{array}{l}\text { Secretary of the Department of } \\
\text { Homeland Security }\end{array}$ & $\begin{array}{c}\text { He will be the Border Security and Cybernetics Officer. He will be in charge of the } \\
\text { Immigration and Customs Enforcement (ICE) with a budget of } 40 \mathrm{~mm} \text {. Military } \\
\text { Chief of the Southern Command (military operations in South and Central } \\
\text { America), Iraq }\end{array}$ \\
\hline James Matis & Head of the Pentagon & $\begin{array}{c}\text { Nicknamed the "crazy dog". Military of Mano Dura was among the first in } \\
\text { Afghanistan when the September } 11 \text { attack ocurred. He was in command of a } \\
\text { division in IRAQ. }\end{array}$ \\
\hline Michel Flynn & National Security Adviser & $\begin{array}{l}\text { Ex - General and Former CIA Agent. Former Director of the Defense Intelligence } \\
\text { Agency (DIA). }\end{array}$ \\
\hline Mike Pompeo & $\begin{array}{c}\text { Director of the Central Intelligence } \\
\text { Agency (CIA) }\end{array}$ & $\begin{array}{l}\text { Republican. Member of the analysts of the attack on Benghazi. He served the US } \\
\text { Armed Forces in Europe and was in the event of the fall of the Berlin Wall. }\end{array}$ \\
\hline \multicolumn{3}{|r|}{ Otheraspects } \\
\hline Scott Priut & $\begin{array}{l}\text { Head of the Environmental } \\
\text { Protection Agency (EPA) }\end{array}$ & Oklahoma State General Counsel \\
\hline
\end{tabular}

From a very basic analysis of the composition of Trump's administration cabinet, it can be considered that there will be continuity in the policies applied in the last two decades and that the case of the migrants will probably be taken as the scapegoat to seek to integrate an ideology that allows to legitimize the new presidency.

\section{Private Banking}

In its Fiscal Monitor report published in October 2016, the IMF warned that the excessive level of non-financial debt (issuance of private and public bonds) -which in 2015 reached 152 billion dollars- could frustrate the recovery of the global economy and produce a new world financial crisis.

The agency is concerned about Western banks, particularly European banks, as the situation of the biggest German bank, Deutsche Bank, and other institutions 
worries the markets. The institution has pointed out that two-thirds of this debt, some 100 billion dollars, consists of private sector liabilities, "which can carry great risks when they reach excessive levels" [12].

Given this scenario what has happened is:

- The IMF's recommendation to implement fiscal policies that support economic activity and facilitate the restructuring of private debt, as well as clean up and eliminate the burden of ineffective bank lending (bailouts).

- In October 2016, European private banks borrowed with an endorsement and the use of an exchange line created with the US Federal Reserve during the financial crisis - 2,800 million dollars from the European Central Bank emergency line (ECB), one of the largest weekly amounts since the financial crisis, because the problems of Deutsche Bank and the more stringent US funding rules that came into effect that month and increase the costs of these operations.

- $\quad$ After the presidential election of November 8, 2016, the big US banks are preparing to approach their Congress with the goal of softening or eliminating the so-called Volcker rule - part of the Dodd-Frank financial reform that Congress launched after of the crisis and the bailouts of 2009 - which prevents the use of depositors' funds for speculative bets, a case that shows the influence of Wall Street against Washington [13].

- The deportations of Mexicans and other Latin Americans out of the US would mean a financial collapse for that country - for the mortgage, commercial and consumer credits of immigrants who were eventually deported - at least 250 billion dollars, and only in the housing sector the loss would be almost 159 billion dollars, (cited for the Condusef) [14].

In the case of commercial banking that operates in our country, it does not face solvency and liquidity problems, it is heavily capitalized; has very attractive levels of profitability to the degree that the subsidiaries are the leverage of the matrices; has low delinquency rates, and its risk coverage and liquidity levels are among the best in the world [15]. These conditions have led commercial banks to:

- $\quad$ Completed a three-year period with the largest credit growth in its history, said Luis Robles Miaja, former president of the Mexican Banking Association, and chairman of the board of directors of BBVA Bancomer [16].

- Increased its share of the economy from $16.2 \%$ of GDP in 2005 to $34 \%$ in 2016 [17] grew by $101 \%$ in 11 years.

- $\quad$ Generated profits in 2016 for 107,007 million of pesos (5,488 million dollars, at an exchange rate of 19.50 pesos per dollar), an increase of $8.3 \%$ over that of 2015 and the second largest in a fiscal year from 2013, when they were 107 thousand 7 million pesos [18].

- During 2010, five banks BBVA Bancomer, Santander, Banorte, Banamex and Inbursa, in that order, concentrated 7 of each 10 pesos of the profits generated by the 47 banking institutions in the country for 82 thousand 481 Million pesos (US $\$ 4.230$ million), equivalent to $77.08 \%$ of the total profits of the banking system.

BBVA Bancomer participated with $31.13 \%$ of the total profits; Santander with 14.72\%; Banorte on $14.06 \%$; Banamex $9.88 \%$, and Inbursa $7.29 \%$ of the total.

- The financial margin of the banking system (difference between the interest they collect and those who pay), reached 377.9 billion pesos in December, 14.8\% more than 2015 [19].

The same source of information said that the banking system's total credit portfolio stood at 4 trillion pesos 339 billion pesos at the end of 2016, $12.9 \%$ higher than a year earlier: five times the growth of the economy, which increased $2.2 \%$.

- $\quad$ Payroll credit is the most attractive financing option and key factor in the business strategies of banks in Latin America during 2016 and 2017 [19]. In June 2016, the portfolio was 5.6 million credits, for a balance of 215.4 billion pesos. The annual real rate charged was $16.4 \%$ per year and accounted for $25.3 \%$ of the total consumer credit portfolio.

- Mortgage lending has become a refuge in which families have managed to protect their resources and build a heritage, said Jesús Eduardo Reyes, general manager of mortgage credit at Banorte [20]. It reached 630 billion pesos, around $12 \%$ of GDP, according to official data and has grown steadily in the last three decades.

Credit to federal and municipal governments up, to December 2016, the total accumulated debt for the years of the public sector amounts to 9 trillion 693 billion pesos (440 601 million dollars), and includes that contracted by the government, Mexican Petroleum (PEMEX), Federal Commission of Electricity (CFE) and banking development, according to data from the SHCP [19]. Regarding the size of the economy was equivalent, at the end of 2016 , to $47.9 \%, 2.1$ percentile points more than in 2015.

Until February 2017, foreign investment in debt securities issued by the government totaled 2 trillion 167 thousand 314 million pesos, an amount that multiplied by eight at the end of 2008, the year of the outbreak of the financial crisis, which was 270 thousand 113 million pesos, according to data from the Mexico's Central Bank as a result of the decrease in interest rates in developed countries that lived the 
crisis raised the flow of financial capital to countries of emerging economies, such as the case of Mexico [21].

Chart 3. Mexico: subnational debt structure by type of creditor and source of payment. 2016

\begin{tabular}{|ccc|}
\hline Creditor & Paymentsource & Participation(\%) \\
\hline \multirow{3}{*}{ Multiple Banking } & Shares & 54.9 \\
& OwnIncome & 3.68 \\
& Contributions & 0.39 \\
\hline \multirow{3}{*}{ Development Bank } & Shares & 20.6 \\
& OwnIncome & 0.47 \\
& Contributions & 1.58 \\
\hline \multirow{3}{*}{ Stock Issues } & Shares & 6.79 \\
& OwnIncome & 9.34 \\
& Contributions & 0.21 \\
\hline \multirow{2}{*}{ Others } & Shares & 1.99 \\
& OwnIncome & 0.39 \\
\hline Total & Contributions & 0.00 \\
\hline
\end{tabular}

Source: SHCP. Portal of Financial Obligations of Federative Entities and Municipalities.

\section{Final Thoughts}

There is enormous vulnerability in the Mexican economy as result of its strong commercial and financial integration with the North American market; in addition, the dominance of the financial system expressed in the behavior of commercial banks has been perpetuated, which has increased its role in the economy, its profits and profitability, and in the hands of foreign capital decisions are represents another area of vulnerability. A third element is the significant holding of public and private debt in the hands of foreigners and also in dollars, mainly from institutional investors, which increasingly puts in trouble the model of opening to foreign investment that unbalances the balance of payments with each change in interest rates and the exchange rate.

In the last years, the products of this author's research have expressed their concern about the type of policies followed by the Mexican government. Now it is necessary to diversify foreign trade with nations that have similar development so they do not reproduce the dependent scheme; to regulate banks and foreign capital in order to allocate their financing to support strategic projects for economic development; to link monetary and fiscal policies in order to direct them first, to the deployment of a huge platform of public and private productive investment with a technological base of first order and, secondly, to eliminate the monetarist approach of the balance of payments for the economic driving.

\section{REFERENCES}

[1] Melo, J. (2012, July-December), La hipótesis de inestabilidad financiera de Minsky en una economía abierta. Ensayos de Economía. 41, 65-88.

[2] Minsky, H. (1992). The Capital Development of The Economy and the Structure of Financial Institutions. The Jerome Levy Institute of Board Collage, Working Paper Num. 72

[3] Keynes, J. M. (1934). A Tratise on Money. The Applied Theory of Money (Vol.2) Ltd. London. Macmillan and Co.

[4] Polanyi, K. (2000). La Gran Transformación. Juan Pablos Editor, Mexico City. ISBN: 968-6454-15-2.

[5] González, R. (2012, May 14), Se vive en el "mundo al revés" en el sistema financiero: Ortíz. La Jornada. Retrieved from http://www.jornada.unam.mx/2012/05/14/economia.

[6] Blancas, A. (2007). Financial fragility dynamics in developing countries. The mexican case. Institute of Economic Research, UNAM. Retrieved from https://ecomod.net/sites/default/files/document-conference/ ecomod2007/452.pdf

[7] Mantey, G. (1997) Lecciones de Economía Monetaria. Unidad Académica de los Ciclos Profesional y de Posgrado (UACPyP) y Facultad de Economía, UNAM. México City.

[8] International Monetary Fund. (2015), Mexico: Selected issues. (IMF Country Report No. 15/314). Washington, DC: Publication Services.

[9] Miranda, J. C. (2017, March 25). Krugman considera remoto que haya cambios radicales al TLCAN. La Jornada. Retrieved from http://www.jornada.unam.mx/2017/03/25/e conomia/022n1eco

[10] Banco de Mexico. (2007). La ventaja comparativa y el desempeño de las exportaciones manufactureras mexicanas en el periodo 1996-2005. (Working Paper No. 2007-12). Mexico City: Chiquiar, D., Fragoso, E. \& Ramos-Francia.

[11] International Monetary Fund. (2015). Spillover implications of differences in monetary conditions in The United States and Euro Area. (Policy Discussion Paper No. 15/01. ISBN/ISSN:9781513551708/1934-7456) Washington, DC: Buitrón, C. \& Vesperoni E.

[12] Notimex, AFP \& Reuters. (2016, October 6), Hay niveles muy elevados de préstamos dudosos en Europa. Bancos preocupan al FMI: excesiva deuda privada, riesgo para la estabilidad. La Jornada. Retrieved from http://www.jornada.unam.mx/2016/10/06/economia/019n2e co.

[13] Reuters. (2017, January 5). Buscan bancos de EU allanar la especulación. La Jornada. Retrieved from http://www.jornada.unam.mx/2017/01/05/economia/018n2e co.

[14] Rodriguez, I. (2017, March 10). Sector financiero de EU perdería 250 mil mdd por deportaciones. La Jornada. Retrieved from http://www.jornada.unam.mx/2017/03/10/e conomia/024n1eco

[15] Calva, J. L. (2013). Análisis estratégico para el desarrollo. Sistema financiero para el desarrollo: La reforma de Peña Nieto y opciones para 2013-2020 (Vol. 6). Mexico City. Casa Juan Pablos Editor.

[16] González, R. (2017d, March 23). La estabilidad ha 
favorecido el mayor crecimiento de crédito. La banca ha tenido un periodo extraordinario en años recientes. $L a$ Jornada. Retrieved from http://www.jornada.unam.mx/201 7/03/23/economia/026e1eco

[17] Gonzales, R. \& Ramírez, I. (2017, March 25). Hay pendientes por superar para construir una sociedad más justa: Marcos Martínez. La Jornada. Retrieved from http://www.jornada.unam.mx/2017/03/25/economia/023n1e co.

[18] Gonzalez, R. (2017b, February 3). Cinco bancos del total que opera en el país generaron 7 de cada $\$ 10$ de utilidad. $L a$ Jornada. Retrieved from http://www.jornada.unam.mx/201 7/02/03/economia/025n 1 eco

[19] Rodriguez, I. (2016, October 11). Crédito de nómina, clave para los bancos. La Jornada. Retrieved from http://www.jornada.unam.mx/2016/10/11/economia/022n2e co

[20] Gonzalez, R. (2017a, January 18). Clara decisión de la banca, sostener el crédito hipotecario. La Jornada. Retrieved from http://www.jornada.unam.mx/2017/01/18/economia/021n2e co

[21] Gonzalez, R. (2017c, March 9). Crece ingreso de capitales golondrinos. La Jornada. Retrieved from http://www.jorna da.unam.mx/2017/03/09/economia/024n1eco

[22] International Monetary Fund. (2016). Informe anual 2016. Juntos buscando soluciones. (Informe Anual 2016, ISBN 9781498349598). Washington, DC: Publication Services. 